\title{
The Measurement of Wood Decay in Landscape Trees
}

\author{
Denise Johnstone, Gregory Moore, Michael Tausz, and Marc Nicolas
}

\begin{abstract}
The evaluation of wood in a tree trunk is essential for tree risk assessment; however, the accurate measurement of decay is still in its infancy. A review of the current methods used for field measurement of wood decay in landscape trees is presented. Methods are compared in terms of the damage caused to tree tissues, ease of use, and their level of accuracy. Moderately invasive decay detecting devices, such as constant feed drills, are accurate for locating wood decay in a tree. In contrast computerized tomography devices are less damaging to tree tissues, but results may be difficult to interpret.

Key Words. Risk trees; Tree Failure; Tree Risk Analysis; Wood Decay.
\end{abstract}

Understanding the processes that result in trunk failure is crucial in the risk assessment of trees (Shigo 1991; Matheny and Clark 1994; Mattheck and Breloer 1994; Mattheck 2007; Schwarze 2008). Tree failure often leads to personal injury or property damage on both private and public land, and trees are regularly removed because they are considered an unacceptable risk and/ or a legal liability (Mortimer and Kane 2004). The decay of wood within a tree trunk is often the cause of tree failure (Lonsdale 1999; Schwarze et al. 2000). This paper reviews the common methods of testing for wood decay in the field and evaluates; (1) the invasiveness and the damage caused to tree tissues, (2) the relative accuracy of assessing wood decay in the field, and (3) the ease of use and difficulty in interpreting the raw data.

Decay is the process by which wood is broken down by microorganisms into simpler forms in order to provide nutrients for their survival (Harris et al. 2004). The devices for measuring wood decay in standing trees are often similar to the equipment used for measuring wood density, as decay results in a decrease in wood density or mass (Beall and Wilcox 1987). The devices reviewed in this paper are grouped into the following categories:

(1) Devices measuring electrical conductivity

(2) Constant feed drills measuring mechanical resistance

(3) Single pulse sonic and ultrasonic devices measuring sonic speed

(4) Devices that use core sampling

(5) Computerized tomography devices

\section{ELECTRICAL CONDUCTIVITY METERS}

The best-known example of an electrical conductivity meter is the Shigometer, which consists of a twisted wire probe and resistance meter (Shigo and Shortle 1985). When operating the device, an electrical probe is placed into a small, pre-drilled hole approximately $3 \mathrm{~mm}$ in diameter. The pattern of resistance of the wood to a pulsed direct current is recorded (Seaby 1991). The main factor determining electrical resistance is the concentration of mobile cations, which is usually very differ- ent between sound and degraded wood (Mattheck and Breloer 1994). Shigo (1991) claimed that in the region adjacent to wood decay, the concentration of cations in the wood would increase and therefore electrical resistance would decrease. However, electrical resistance also decreases if wood is healthy but dry (Nicolotti and Miglietta 1998), and increases in dry decayed wood and when the probe moves from sapwood to heartwood (Shigo 1991). Electrical resistance may also decrease when the probe reaches bacterial wetwood (Nicolotti and Miglietta 1998).

Several researchers have had very inconsistent results with the Shigometer. Results have been dependent on the tightness of fit of the electrode and the relative moisture and resin content of the timber (Seaby 1991). Shigo and Shortle (1985) advise that the Shigometer will not function in resin soaked, frozen or dead wood and the operator should carefully control the amount of contact the needle electrodes have with the wood. Wilkes and Heather (1983) claimed the Shigometer might not be able to detect decay in eucalypts because mineral levels and the $\mathrm{pH}$ of the wood did not change in a consistent pattern. The Shigometer was also not able to detect decay in New Zealand red beech (Nothofagus fusca) (Wilson et al. 1982). Shigo and Shortle (1985) acknowledged the variability of species when using their equipment and recommended establishing a baseline for healthy sound trees by first measuring electrical resistance from a large random sample.

The Plant Impedance Ratio Meter is similar to the Shigometer. The device measures the impedance of an alternating current at two frequencies (Blazé 1992). The high frequency reading (10 $\mathrm{kHz})$ is divided by the low frequency reading $(1 \mathrm{kHz})$; hence the output is a "ratio." The magnitude of an alternating current passing through a plant tissue is called the admittance of the tissue. It is claimed that the admittance of the cell walls of similar tissues of a plant is the same at all frequencies. The ratio of the higher to lower frequencies will therefore be greater than one in healthy tissue. The ratio measured by the Plant Impedance Ratio Meter is therefore not affected by moisture content or temperature, unlike the Shigometer (Harris 1992). In practical terms, the gathering of impedance data with a twisted wire probe in a $3 \mathrm{~mm}$ diameter hole 
to any great depth in a tree is more difficult than using a constant feed drill that is able to gather data as it drills. As with the Shigometer, results must be dependent on the tightness of fit of the electrode (Seaby 1991). The advantage of the Plant Impedance Ratio Meter is in the measurement of the vitality of tissues near the surface (with double-needle pins, rather than a long probe) rather than in decay detection in the deeper tissues of the tree. Tree vascular tissues must be wounded to the depth of desired decay detection.

The four-point resistivity (RISE) method passes a current through an object with one pair of electrodes, while measuring the voltage difference with another pair of electrodes (Larsson et al. 2004). The constant current is passed vertically though the stem rather than horizontally. The resistivity must be measured against other trees of similar water content and species and at a similar temperature and humidity and must be normalized for stem cross-sectional area. It cannot be used to assess the volume or location of the decay.

\section{CONSTANT FEED DRILLS}

Constant feed drills are simple drills that control and measure the rate of feed of a drill bit, and map the results either electronically or onto a graph. The most common devices for tree inspection are the Resistograph (also known as the IML-Resistograph or the IML-Resi) and the Sibert DDD 200. A simple mechanical drill has also been used as a decay-detecting device, where the drill operator senses the changes in drill resistance and evaluates the wood shavings (Costello and Quarles 1999).

The Resistograph is a portable, constant feed drill that records on a strip chart or electronic data recorder the drilling resistance as the bit penetrates the tree at a constant drive (Mattheck et al. 1997). The amplitude of the graph trace indicates resistance. Decay in the path of the drill is represented by a fall in drilling resistance. A shaft covers the drill bit to prevent the operator forcing the drill faster than the constant drive. The drill bit tip (needle) is $3 \mathrm{~mm}$ wide (Bethge et al. 1996). The penetration speed may be set on the device and the depth of drive is $300-1500 \mathrm{~mm}$, so it has the potential to be used on quite large diameter trees (Rinn et al. 1996).

A study compared the Resistograph to drilling with a portable drill in Victorian blue gum (Eucalyptus globulus) and golden elm (Ulmus glabra) (Costello and Quarles 1999). Wood density levels below a critical level (less than $500 \mathrm{~kg} \mathrm{~m}^{-3}$ ) in Victorian blue gum and golden elm (less than $400 \mathrm{~kg} \mathrm{~m}^{-3}$ ), were considered decayed. The depth to the point of decay was grouped into three categories $0-5 \mathrm{~cm}, 6-10 \mathrm{~cm}$, and $11-15 \mathrm{~cm}$. For Victorian blue gum, $85.5 \%$ of Resistograph and $73 \%$ of the portable drill results were in a $0-5 \mathrm{~cm}$ deviation from accuracy category. For golden elm, 100\% of Resistograph and $81 \%$ of the portable drill method were in the $0-5 \mathrm{~cm}$ deviation from accuracy category. This is a very accurate result for the Resistograph and a moderately accurate result for the portable drill.

The IML-Resi was tested in conjunction with an "expert system" to assess the accuracy of decay detection in Victorian blue gum (Eucalyptus globulus subsp. pseudoglobulus) (Johnstone et al. 2007). The compartmentalization of decay in trees (or CODIT) model (Shigo 1979) was combined with raw data from the IMLResi to predict the cross-sectional area of decay. A statistically significant relationship was established between the predicted total area of decay in a wood section and the actual area of decay. Using a linear regression analysis of variance, $76 \%$ of the variation in the readings could be explained by the predicted area of decay.
Correlations between wood density charts and the Resistograph measurements have been established for air seasoned wood samples in six tree species: European silver fir (Abies alba), European larch (Larix decidua), Norway spruce (Picea abies), Swiss pine (Pinus cembra), bigleaf linden (Tilia platyphyllos), and a poplar (Populus sp.) (Rinn et al. 1996). A progeny trial Isik and $\mathrm{Li}$ (2003) found a weak to moderate relationship between wood density and the amplitude of drilling resistance in loblolly pine (Pinus taeda L.). A strong correlation between average wood density and resistance was also found in Victorian blue gum (Johnstone 2005). The sensitivity of the Resistograph (or the IML-Resi) to wood properties meant that drill resistance was affected by the moisture content of the wood (Rinn et al. 1996; Lin et al. 2003), but not in Victorian blue gum (Johnstone 2005).

An English prototype for a constant feed drill was developed, the "Decay Detecting Drill" (DDD), with a $2 \mathrm{~mm}$ flared drill bit tip (Seaby 1991). The number of revolutions per $\mathrm{cm}$ of penetration was plotted against wood density $\left(\mathrm{kg} \mathrm{m}^{-3}\right)$ to test the device's effectiveness. According to Seaby (1991), there was a direct relationship between wood density and resistance except when there was variable moisture content in the sample. Rotational drag did not affect the results but longitudinal drag reduced drill bit tip pressure by approximately $10 \% \mathrm{~cm}^{-1}$. This meant that the drill produced results that indicated wood density increased with the depth of penetration, even when this was not the case.

Seaby (1991) speculated that better drill bit tip design might improve drag. The DDD 200 is faster than the Resistograph but provides less data per millimeter (Nicolotti and Miglietta 1998). Both the Resistograph and another device, the Densitomat-400, have a probe design that cuts a hole wider than the drill shaft, which may reduce resistance problems. Probes of constant feed drills are flexible, causing inconstancies in the data if the probe rubs against the side of the hole, and may cause deviations in the drilling path (Nicolotti and Miglietta 1998; Dolwin 1999). Other possible causes of drill bit drag may be the sharpness of the drill bit and the heating of the drill bit. Heating as a cause of drill bit drag however is very unlikely as most drill bits are steel, and the coefficient of area of expansion for steel is $24 \times 10^{-6}$ for every $1{ }^{\circ} \mathrm{C}$ (Giancoli 2005). Thus, even if a drill bit heated to $500^{\circ} \mathrm{C}$, which is very unlikely, only a $1 \%$ increase in the crosssectional area would occur. Moore (1999) found that drill bit drag (or friction) was severe enough to prevent the detection of decay by the Resistograph, a result inconsistent with others (Costello and Quarles 1999; Nicolotti et al. 2003; Johnstone et al. 2007).

Kersten and Schwarze (2005) found that the IML-Resistograph provides a substrate for decay fungi as shavings from drilling retained in the hole, and Toussaint et al. (2004) found decay increased along drill-needle paths in Tilia sp. (Linden). As a result of Resistograph drilling, Helliwell (2007) found both $6 \mathrm{~mm}$ and $10 \mathrm{~mm}$ drills resulted in wood staining and discoloration two years after the holes had been drilled. Weber and Mattheck (2006) argued that constant feed drills did not result in long-term decay. They claimed that negative short-term wood decay was counteracted by the successful formation of compartmentalization reaction zones (Shigo 1979), after a longer period of 8-10 years (Weber and Mattheck 2006). No decay extended past the compartmentalization barrier zone (Shigo 1979), in any of the trees they tested, and there was no decay in trees with no preexisting decay prior to drilling. 


\section{SINGLE PULSE SONIC AND ULTRASONIC TECHNIQUES}

The velocity of the propagation of sound waves is much faster in wood than in air (Bootle 2005). In a solid medium, the velocity of a sound depends on the type of wave and the elasticity and density of the material (Pollard 1968). Acoustic instruments usually measure the wave velocity $(v)$ in wood. The wave velocity in $\mathrm{m} \mathrm{s}^{-1}$ is given by:

Equation $\quad v=\sqrt{\frac{E}{\rho}}$

Where $\mathrm{E}$ is the modulus of elasticity and $\rho$ is the density (Ouis 2003). Velocity is therefore dependent on factors such as species, moisture content, temperature, and the anatomical direction in which the sound is transmitted (Mishiro 1996). It is also difficult to translate the velocity of sound to physical properties, because wood is an anisotropic material (Nicolotti et al. 2003; Socco, et al. 2004; Bucur 2006a; Maurer et al. 2006; Schubert et al. 2009).

Most instruments for ultrasonic analysis operate at frequencies between $50 \mathrm{kHz}$ to $5 \mathrm{MHz}$ (Bucur 2003). Instruments operating above $1 \mathrm{MHz}$ can create images of the objects they scan as resolution increases at these frequencies (Bucur 2003). To minimize attenuation of the ultrasound signal the frequency of the signal must be low, but this results in decreased resolution and, in some instances, the wavelength of the signal may be large enough that regions of different wood densities may be obscured (Ouis 2003; Socco et al. 2004).

The Fujikura-Arborsonic Decay Detector is based on a simple pulse-echo method measuring the transmission time of an ultrasound pulse (Wade 1975). It delivers an ultrasound pulse of $77 \mathrm{kHz}$ that passes through the stem. The signal speed is approximately $2000 \mathrm{~m} \mathrm{~s}^{-1}$ through undegraded cell walls. In timber, the usual mode of propagation of ultrasound is via the cell walls. When cells are degraded the ultrasound signal speed is slowed; the more decay the slower the signal. The Fujikura-Arborsonic Decay Detector operates using a transducer (which sends the signal) and a receiver (that receives the signal) on opposite sides of the tree. A $45 \mathrm{~mm}$ diameter bark plug is first removed to provide good contact to the wood. The known distance between the transducers in millimeters is divided by two to obtain the expected ultrasound propagation time reading in microseconds. The expected times are given in a table according to the diameter of the tree. It does not produce a tomographic image. The maximum recommended tree diameter for the Fujikura-Arborsonic Decay Detector is $1.4 \mathrm{~m}$. Larger trees require quadrant testing, with transducers and receivers at 90 -degrees to one another, rather than at opposite sides of the tree. As decay deep in the core of the tree is not as important a concern in larger trees, testing in this way is appropriate (Smiley 1992).

Single pulse ultrasonic devices were able to detect various types of defects and changes in wood quality in some trees (Nicolotti and Miglietta 1998; Sandoz 1999). Decayed wood did not significantly reduce the transmission time of the signal produced by the Fujikura-Arborsonic Decay Detector in Victorian blue gum, a result inconsistent with willow oak (Quercus phellos L.) and nuttall oak (Quercus nuttallii E.J. Palmer), where decay did reduce transmission times (Xu et al. 2000; Johnstone 2005). The Fujikura-Arborsonic Decay Detector per- formed slightly better on spotted gum (Corymbia maculata) samples that were hollow, but was not successful at all in hollow willow oak or nuttall oak (Xu et al. 2000; Johnstone 2005). As with the Silvatest that requires stripping pieces of bark 30 $\mathrm{mm}$ in diameter to provide good contact (Nicolotti and Miglietta 1998), another disadvantage as "noninvasive" test instruments is bark must be taken from the trunk, thus wounding the tree.

Stress wave assessment is another method of assessing wood using sonics, rather than ultrasonics. A stress wave is a complex mixture of frequencies, various components of which travel through solid, liquid, and gas with differing velocities (Wade 1975). Stress wave assessment of wood has been successfully modeled in utility poles in laboratory settings (Bulleit and Falk 1985). The Metriguard Stress Wave Timer uses this approach (Mattheck and Bethge 1993). A hammer struck against pins inserted into the xylem sends a signal across the trunk. It detects changes in wood quality but may be less accurate than ultrasound because of the number of frequencies involved. The Metriguard requires speciesspecific reference tables. Inconsistencies in readings can occur because the hammer is not always struck with the same force (Nicolotti and Miglietta 1998). Interpretation is complicated as the velocity of the sound may be slowed by bacterial wetwood, decay, and in some cases inaccurate measurement due to excessive wind speed (Mattheck and Bethge 1993; Yamaguchi et al. 2001). Perhaps the best use for single path stress wave time-of-flight testing is, as Wang and Allison (2008) suggest, as an initial screening process that may justify more sophisticated investigations.

A more advanced analysis of acoustic single path stress waves can be performed by reworking the data using Fourier transformations (Lawday and Hodges 2000). Short-time Fourier transforms of stress waves predict the extent of wood decay, rather than just the presence of decay. Acoustic techniques utilizing multiple path stress waves are classed as "tomography" techniques and are discussed in a following section.

\section{BREAKING CORE SAMPLES}

Fractometers measure decay by assessing the mechanical properties of an extracted core of wood. The Fractometer I measures the force required to bend a core sample (radial bending fracture strength) and the radial angle prior to breaking (stiffness) (Bethge et al. 1996). Fibers and wood rays must be oriented parallel to the front of the Fractometer, which, the developers claim, simulates the fiber loading due to wind (Mattheck et al. 1995). Measurement is in "fractometer units" (FU), which can be converted into units of pressure (MPa) (Bethge et al. 1996).

The theoretical basis for developing the Fractometer is clearly Hooke's law, which states that a change in form is proportional to the deforming force or $\mathrm{F}=\mathrm{k} \Delta \mathrm{L}$, where $\mathrm{F}$ is the force pulling on an object, $\Delta \mathrm{L}$ is the increase in length, and $\mathrm{k}$ is a proportionality constant (Giancoli 2005). The change in form on the Fractometer sample is measured by the angle setting and the deforming force by the pressure required to break the sample. The modulus of elasticity can be derived from Hooke's law and is the constant " $\mathrm{k}$ " (Pollard and Harris 1968).

The size of the sample cores used in the Fractometer $(5 \mathrm{~mm}$ diameter) largely precludes the use of the device in trees that have high wood density. Species such as eucalypts usually require increment coring with a motorized corer (Downes et al. 1997). Motorized increment corers yield a $12 \mathrm{~mm}$ sample too large to be tested by the 
Fractometer. When intact, $5 \mathrm{~mm}$ cores were obtained from Victorian blue gum (Matheny et al. 1999); they broke when the lever arm was placed against the sample and no results could be recorded.

Bethge et al. (1996) observed that the Fractometer distinguished between types of decay. Brown rot leads to very small fracture angle whilst advanced white rot results in much larger angles. Timber in which lignin is degraded may appear to resist bending but does not have the stiffness of less decayed wood. On the other hand, timber with cellulose degradation will be low in elastic strength but stiff. Timber that is not decayed will be very stiff but also very strong.

The Fractometer II determines the longitudinal compression failure strength as well as the radial fracture bending strength (Fractometer I measures the latter only) (Bethge et al. 1996). Fractometer III measures all of the above, the tangential bending fracture strength, and the radial and tangential shear strength. The developers maintain however that the only necessary Fractometer for successful field diagnosis is the Fractometer I, as excessive fiber loading is most common in the radial direction. Methods that require core sampling are some of the most invasive of the decay detecting devices, causing decay in yellow birch (Betula lutea Michx.) basswood (Tilia americana L.) and sugar maple (Acer sacchrum Marsh.) (Lorenz 1944). However, core sampling did not contribute to tree mortality over a 12-year period in white fir (Abies concolor), which is said to decay rapidly after mechanical wounding, and red fir (Abies magnifica) (van Mantgem and Stephenson 2004).

\section{COMPUTERIZED TOMOGRAPHY}

Computerized tomography can employ acoustic rays, electrical resistance, and thermal or radar techniques (Nicolotti et al. 2003). For electrical resistance and acoustic measurements, sensors are usually placed around a tree (from 8-16 but occasionally more), and multiple measurements are gained by sending a signal from one sensor to the others (Nicolotti et al. 2003; Gilbert and Smiley 2004; Bucur 2006b). In radar or thermal imaging techniques, the signal is delivered and allowed to bounce off internal, and in the case of thermal imaging, external structures (Bucur 2003; Nicolotti et al. 2003; Catena and Catena 2008). These instruments produce cross-sectional "pictures" of the stem, via a computer programmed with complex conversion algorithms. X-rays, microwave technology, nuclear magnetic resonance (NMR) and neutron imaging for decay detection are all possible, but are currently very expensive and usually used for more sophisticated scanning of wood properties (Bucur 2003).

Thermal imaging with an infrared camera scans for wood defects but cannot accurately quantify the amount of wood decay (Catena and Catena 2008). Images are species specific. Thermography cannot assess residual wall thicknesses (Catena 2003). Thermal imaging has the advantage of being noninvasive. It can detect wood decay in large tree roots or the root collar (Catena 2003; Catena and Catena 2008).

Georadar devices are usually used to locate tree roots (Ouis 2003; Hagrey 2007). Images are generated via the reflection of electromagnetic waves (Nicolotti et al. 2003). Georadar techniques were successful in detecting wood decay in the study by Nicolotti et al. (2003), but required considerable processing of the data. Georadar is noninvasive.

Nicolotti et al. (2003) assessed results from electrical resistance and ultrasonic tomography and georadar. They reported good results with electric tomography but the number of replicates was two. Electrical tomography was deemed promising by Hagrey (2007), but results were qualitative rather than quantitative. Problems with the Shigometer in eucalypts may be similar to electrical tomography, as the raw data is the same (electrical resistance). However the electric tomography described by Nicolotti et al. (2003) is less invasive than the other electrical resistance devices, because the electrodes are only driven into a depth of $10 \mathrm{~mm}$ rather than placed in a predrilled hole.

The PUNDIT (Portable Ultrasonic Nondestructive Digital Indicating Tester) uses ultrasonic tomography. The operating frequency of the PUNDIT is $33 \mathrm{kHz}$ and it is possible with the 16 sensors to obtain 120 travel time measurements for each trunk cross-section (Nicolotti et al. 2003; Socco et al. 2004). Signal processing for the data collected in the study by Nicolotti et al. (2003) was carried out with Migratom software. Two samples used in the study were London plane (Platanus hybrida Brot.), and were decayed rather than hollow in the center, with strength losses of between $22.7 \%$ and $53.6 \%$ (Nicolotti et al. 2003). Moisture content was higher in the decayed zones than in the surrounding sound wood. The ultrasonic transducers were used with a coupling gel placed directly on the bark, but without removing a bark plug. The ultrasonic signal can be processed by a cathode ray oscilloscope to further manipulate and control the data supplied by the PUNDIT (Socco et al. 2004).

The Picus Sonic Tomograph uses sonic tomography. Raw data is the time of transmission of the sound of a hammer tap on one sensor to each other sensor, 8-12 for each stem cross-section (Gilbert and Smiley 2004). The Picus is selfcalibrating in that the fastest acoustic transmission time relative to distance is deemed "sound" wood (Rabe et al. 2004; Schwarze 2008). A sound wave produced manually is called a stress wave (Wade 1975; Bulliet and Falk 1985; Mattheck and Bethge 1993). A disadvantage of the Picus over the PUNDIT is the Picus does not deliver a sound pulse of known frequency, which can lead to inaccuracies in recording the speed of propagation time (Nicolotti et al. 2003). It is possible to deliver sonic waves at predictable and repeatable frequencies (Schubert et al. 2009) but this is not the mode of operation of the Picus. The conversion algorithm for both stress and ultrasound waves is complex because the propagation of sound is not always in a straight line (Bucur 2003; Maurer et al 2006).

Gilbert and Smiley (2004) evaluated the Picus for location and extent of decay. Decay was defined as both an absence of wood and wood that could be deflected with finger pressure. There was a high correlation between the amount of decay detected by the Picus and the extent of decay assessed visually, following felling $\left(r^{2}=0.90\right)$ (Gilbert and Smiley 2004). The Picus slightly underestimated decay in most cases, with an average discrepancy of $6 \%$. The stem cross-sections exhibited decay not detected by the Picus in $9 \%$ of the readings. The range for error was from minus $3 \%$ to minus $20 \%$. Tree diameter ranged from $250 \mathrm{~mm}$ to $490 \mathrm{~mm}$ (Gilbert and Smiley 2004). Similar results were obtained by Rabe et al. (2004). Decay in the sapwood was not accurately assessed (Deflorio et al. 2008), and was dependent on the host/pathogen combination. The precise location of the decay was also found to be less accurately represented by the Picus in some studies (Rabe et al. 2004; Wang and Allison 2008). The Picus is minimally invasive, as $2 \mathrm{~mm}$ nails are inserted a few millimeters into the xylem (Gilbert and Smiley 2004). 
Bacterial wetwood, cavities, and cracks produce inaccuracies in Picus data processing and may be interpreted as areas of decay (Schwarze and Heuser 2006; Wang et al. 2007; Schwarze 2008; Wang and Allison 2008; Wang et al. 2009). The position of decay within the trunk reduces the accuracy of decay assessment using sonic or ultrasonic wave velocity (Deflorio et al. 2008; Lin et al. 2008; Wang et al. 2009), although recent advances in signal processing and data interpretation may improve this problem (Socco et al. 2004). Lin et al. (2008) found that ultrasonic velocities decreased when the size of a manually created circular hole in a cross-section (simulating decay in a cross-section) in $30-35 \mathrm{~cm}$ cross-sections increased, but not always in a clear linear relationship. Sections where a predrilled hole was 9-11 cm in diameter showed a blue area (denotes slowest sonic velocities), 11-21 cm diameter predrilled holes showed a green area (denotes third slowest sonic velocities), and predrilled holes more than $21 \mathrm{~cm}$ in diameter showed a violet area (denotes second slowest sonic velocities). Schubert et al. (2009) found that cavities greater than $5 \%$ of the cross-section of a tree trunk could be detected under laboratory conditions by sonic tomography, by converting a digital signal to analog, rather than using manually generated stress waves as with the Picus. Maurer et al. (2006) found that very low velocity areas are difficult to identify within areas where acoustic velocities are already decreased when using the Picus.

The sound frequency of the trunk has also been used experimentally to assess Norway spruce wood decay (Axmon 2004). First the surface (circumferential) wave velocity is measured, and must be above a minimum level in order to allow for sources of error such as low moisture or decayed outer sapwood. The theoretical modal frequency is then calculated for a sound tree using the surface wave velocity. A significant deviation from the modal frequency would indicate decay or a defect in the stem. Currently, this technique requires as many sensors as the Picus or PUNDIT instruments, and it is not yet as accurate for detecting decay, but eventually only two or three sensors may be required, greatly reducing the time taken to measure an individual tree.

\section{CONCLUSION}

Assessing decay in tree trunks remains in its infancy and is problematic. Devices vary considerably in their invasiveness, reliability, ease of use, and interpretation. The variable moisture content of green and decayed wood may reduce the accuracy of acoustic devices, constant feed drills, and conductivity meters. Devices using electrical conductivity require a high level of specialized knowledge and experience in their use. Core sampling techniques are the most damaging to the xylem and rely heavily on the correct orientation of samples. Core sampling is portable and inexpensive. Constant feed drills and most conductivity meters are also invasive instruments, though less so than the core sampling techniques. Ultrasound and stress wave techniques can offer detailed information on the quality of wood tested, but there may be difficulty in distinguishing between decayed wood and bacterial wetwood, or between decayed wood and cavities. Single pulse ultrasound and stress wave equipment is expensive and requires removing bark plugs.

Tomographic technologies yield an accurate assessment of decay compared to core sampling, single sample conductivity and single pulse sonic devices. Tomography is less invasive than constant feed drills and core sampling devices, despite being less able to indicate the location, and in some instances the quantity, of decay. Thermal imaging and radar tomography are completely noninvasive, but appear to be less accurate in calculating the quantity of decay. Sonic or ultrasonic tomography seems to offer agood balance between accuracy, invasiveness, and ease of use, but at high cost.

Acknowledgments. We would like to thank the anonymous reviewers for their time, careful consideration, and editing of this article.

\section{LITERATURE CITED}

Axmon, J., M. Hansson, and L. Sörnmo. 2004. Experimental study on the possibility of detecting internal decay in standing Picea abies by blind impact response analysis. Forestry 77:179-192.

Beall, F., and W. Wilcox. 1987. Relationship of acoustic emission during radial compression to mass loss from decay. Forest Products Journal $37: 38-42$

Bethge, K., C. Mattheck, and E. Hunger. 1996. Equipment for detection and evaluation of incipient decay in trees. Arboricultural Journal 20:13-37.

Blazé, K. 1992. Electronic assessment of tree condition. Scientific management of Plants in the Urban Environment. editors, Moore, G. P. May, J. Hitchmough, J. Delpratt, P. Kenyon and P. Esdale, Conference Proceedings. Melbourne, Centre for Urban Horticulture. pp. 135-145.

Bootle, K.R. 2005. Wood in Australia (2nd Edition). Sydney, McGrawHill. 452 pp.

Bucur, V. 2003. Nondestructive Characterization and Imaging of Wood. Berlin, Springer-Verlag. 354 pp.

Bucur, V. 2006a. Acoustics of Wood (2nd Edition). Berlin, SpringerVerlag. 393 pp.

Bucur, V. 2006b. Urban Forest Acoustics. Berlin, Springer-Verlag. 181 pp.

Bulleit, W. M., and R.H. Falk. 1985. Modeling stress wave passage times in wood utility poles. Wood Science and Technology 19:183-191.

Catena, A. 2003. Thermography reveals hidden tree decay. Arboricultural Journal 27:27-42.

Catena, A., and G. Catena. 2008. Overview of thermal imaging for tree assessment. Arboricultural Journal 30:259-270.

Costello, L., and S. Quarles. 1999. Detection of wood decay in blue gum and elm: an evaluation of the IML-Resistograph and the portable drill. Journal of Arboriculture 25:311-317.

Deflorio, G., S. Fink, and F.W.M.R. Schwarze. 2008. Detection of incipient decay in tree stems with sonic tomography after wounding and fungal infection. Wood Science Technology 42:117-132.

Dolwin, J.A., D. Lonsdale, and J. Barnett. 1999. Detection of decay in trees. Arboricultural Journal 23:139-149.

Downes, G.M., I.L. Hudson, C.A. Raymond, G.H Dean, A.J. Michell, L.R. Schimleck, R. Evans, and A. Muneri. 1997. Sampling Plantation Eucalypts for Wood and Fibre Properties. Canberra, CSIRO Publishing. $132 \mathrm{pp}$.

Giancoli, D.C. 2005. Physics. Principles with Applications (6th Edition). New Jersey, Pearson Prentice Hall. 1004 pp.

Gilbert, E., and E. Smiley. 2004. Picus sonic tomography for the quantification of decay in white oak (Quercus alba) and hickory (Carya spp.). Journal of Arboriculture 30:277-281.

al Hagrey, S. 2007. Geophysical imaging of root-zone, trunk, and moisture heterogeneity. Journal of Experimental Botany 58:839-854.

Harris, R.W. 1992. Arboriculture. Integrated Management of Landscape Trees, Shrubs, and Vines (2nd Edition). New Jersey, Prentice Hall. $674 \mathrm{pp}$ 
Harris, R.W., J.R. Clark, and N.P. Matheny. 2004. Arboriculture. Integrated Management of Landscape Trees, Shrubs, and Vines (4th Edition). New Jersey, Prentice Hall. 578 pp

Helliwell, D.R. 2007. A short note on effects of boring holes in trees. Arboricultural Journal 30:245-248.

Isik, F., and B. Li. 2003. Rapid assessment of wood density of live trees using the IML-Resistograph for selection in tree improvement programs. Canadian Journal of Forest Research 33:2426-2435.

Johnstone, D.M. 2005. The field assessment of wood decay and wood density in eucalypts. Master of Forest Science Thesis. Melbourne, University of Melbourne. 221 pp.

Johnstone, D.M., P.K. Ades, G.M. Moore, and I.W. Smith. 2007. Predicting wood decay in eucalypts using an expert system and the IMLResistograph drill. Arboriculture \& Urban Forestry 33:76-82.

Kersten, W., and F.W.M.R. Schwarze. 2005. Development of decay in the sapwood of trees wounded by the use of decay-detecting devises. Arboricultural Journal 28:165-181.

Larsson, B., B. Bengtsson, and M. Gustafsson. 2004. Nondestructive detection of decay in trees. Tree Physiology 24:853-858.

Lawday, G., and P.A. Hodges. 2000. The analytical use of stress waves for the detection of decay in standing trees. Forestry 73:447-456.

Lin, C.-J., Y.-C. Kao, T.-T. Lin, M.-J. Tsai, S.-Y. Wang, L.-D. Lin, Y.N. Wang, and M.-H. Chan. 2008. Application of an ultrasonic tomographic technique for detecting defects in standing trees. International Biodeterioration \& Biodegradation 62:434-441.

Lin, C.-J., S.-Y. Wang, F.-C. Lin, and M.-C. Chiu. 2003. Effect of moisture content on drill resistance value in Taiwania plantation wood. Wood and Fiber Science 35:234-248.

Lonsdale, D. 1999. Principles of Tree Risk Assessment and Management. London, The Stationery Office. 388 pp.

Lorenz, R.C. 1944. Discolorations and decay resulting from increment borings in hardwoods. Journal of Forestry 42:37-43.

van Mantgem, P.J., and N.L. Stephenson. 2004. Does coring contribute to tree mortality? Canadian Journal of Forest Research 34:2394-2398.

Matheny, N.P., and J.R. Clark. 1994. A Photographic Guide to the Evaluation of Risk Trees in Urban Areas, International Society of Arboriculture, Champaign, IL, U.S.A. 85 pp.

Matheny, N., J. Clark, D. Attewell, K. Hillery, A. Graham, and G. Posner. 1999. Assessment of fracture moment and fracture angle in 25 tree species in the United States using the fractometer. Journal of Arboriculture 25:18-23.

Mattheck, C. 2007. Updated Field Guide for Visual Tree Assessment. Karlsruhe, Karlsruhe Research Center, 170 pp.

Mattheck, C., and K. Bethge. 1993. Detection of decay in trees with the metriguard stress wave timer. Journal of Arboriculture 19:374-378.

Mattheck, C., and H. Breloer. 1994. Field guide for visual tree assessment (VTA). Arboricultural Journal 18:1-23.

Mattheck, C.G., H. Breloer, K.A. Bethge, W.A. Albrecht, and A.W. Zipse. 1995. Use of the fractometer to determine the strength of wood with incipient decay. Journal of Arboriculture 21:105-112.

Mattheck, C., K. Bethge, and W. Albrecht. 1997. How to read the results of Resistograph M. Arboricultural Journal 21:331-346.

Maurer, C., S.I. Schubert, F. Bächle, S. Clauss, D. Gsell, J. Dual, and P. Niemz. 2006. A simple anisotropy correction procedure for acoustic wood tomography. Holzforschung 60:567-573.

Mishiro, A. 1996. Effect of density on ultrasonic velocity in wood. Mokuzai Gakkaishi 42:887-894.

Moore, W. 1999. The combined use of the Resistograph and the Shigometer for the accurate mapping and diagnosis of the internal con- dition of woody support organs of trees. Arboricultural Journal 23: 273-287.

Mortimer, M.J., and B. Kane. 2004. Risk tree liability in the United States: Uncertain risks for owners and professionals. Urban Forestry and Urban Greening 2:159-165.

Nicolotti, G., and P. Miglietta. 1998. Using high-technology instruments to assess defects in trees. Journal of Arboriculture 24:297-302.

Nicolotti, G., L.V. Socco, R. Martinis, A. Godio, and L. Sambuelli. 2003. Application and comparison of three tomographic techniques for detection of decay in trees. Journal of Arboriculture 29:66-77.

Ouis, D. 2003. Non-destructive techniques for detecting decay in standing trees. Arboricultural Journal 27:159-177.

Pollard, H. F., and R.W. Harris. 1968. Introductory Physical Acoustics. Sydney, New South Wales University Press. 105 pp

Rabe, C., D. Ferner, S. Fink, and F.W.M.R. Schwarze. 2004. Detection of decay in trees with stress waves and interpretation of acoustic picus images. Arboricultural Journal 28:3-19.

Rinn, F., F.H. Schweingruber, and E. Schar. 1996. Resistograph and $\mathrm{X}$-ray density charts of wood comparative evaluation of drill resistance profiles and X-ray density charts of different wood species. Holzforschung 50:303-311

Sandoz, J.L. 1999. Standing tree quality assessments using ultrasound International Symposium on Urban Tree Health. M. Lemattre, P. Lemattre, and F. Lemaire (Eds.). Conference Proceedings. Acta Hortculturae 496:269-277.

Schubert, S., D. Gsell, J. Dual, M. Motavalli, and P. Niemz. 2009. Acoustic wood tomography on trees and the challenge of wood heterogeneity. Holzforschung 63:107-112.

Schwarze, F.W.M.R., 2008. Diagnosis and Prognosis of the Development of Wood Decay in Urban Trees. Rowville, Enspec 336 pp

Schwarze, F.W.M.R., J. Engels, and C. Mattheck. 2000. Fungal Strategies of Wood Decay in Trees. Berlin, Springer-Verlag. 185 pp

Schwarze, F.W.M.R., and C. Heuser. 2006. Stem wounds - potential entry courts for wood decay fungi? Arboricultural Journal 29:101-119.

Seaby, D.A. 1991. Recent advances in detection of wood decay. Research for Practical Arboriculture. S.J. Hodge (Ed.). University of York, HMSO. 3:168-176.

Shigo, A.L. 1979. Tree decay: an expanded concept. USDA Forest Service Information Bulletin 419. 72pp.

Shigo, A.L., and W.C. Shortle. 1985. Spruce Budworms Handbook: Shigometry - A Reference Guide. Agriculture Handbook No 646: U.S. Department of Agriculture, Forest Service, Cooperative State Research Service. 48pp.

Shigo, A.L. 1991. Modern Arboriculture, Shigo \& Trees, New Hampshire. $421 \mathrm{pp}$.

Smiley, E. T., and B.R. Fraedrich. 1992. Determining strength loss from decay. Journal of Arboriculture 18:201-204.

Socco, L.V., L. Sambuelli, R. Martinis, E. Comino, and G. Nicolotti. 2004. Feasibility of ultrasonic tomography for nondestructive testing of decay on living trees. Research in Nondestructive Evaluation $15: 31-54$.

Toussaint, A., J.P. Baudoin, B. Campanella, and R. Paul. 2004. The impact of Resistograph on tree decay. International Congress on the Trees of History. G. Nicolotti and P. Gonthier (Eds.). Conference Proceedings. Torino, Università di Torino. pp. 148-150.

Wade, P.J. 1975. The Fujikura-Arborsonic Decay Detector Concept, Development \& Operation. Fujikura Europe Limited. 11 pp.

Wang, X., R.B. Allison, L. Wang, and R.J. Ross. 2007. Acoustic tomography for decay detection in red oak trees. Research Paper FPL-RP-642. 
Madison, WI: U.S. Department of Agriculture, Forest Service, Forest Products Laboratory. $7 \mathrm{pp}$.

Wang, X., and R.B. Allison. 2008. Decay detection in red oak trees using a combination of visual inspection, acoustic testing, and resistance microdrilling. Arboriculture and Urban Forestry 34:1-4.

Wang, X, J. Wiedenbeck, and S Liang. 2009. Acoustic tomography for decay detection in black cherry trees. Wood and Fiber Science 41:127-137.

Weber, K., and C. Mattheck. 2006. The effects of excessive drilling diagnosis on decay propagation in trees. Trees Structure and Function 20:224-228

Wilkes, J., and W.A. Heather. 1983. Correlation of resistance to a pulsed current with several wood properties in living eucalypts. New Zealand Journal of Forestry Science 13:139-135.

Wilson, P. J., J.D. Allen, and J.C.F. Walker. 1982. Appraisal of the Shigometer Technique. New Zealand Journal of Forestry Science 12:86-95.

Yamaguchi, T., K. Sasaki, and Y. Sakamoto. 2001. Evaluation of a stress-wave timer for the minimally destructive detection of decay in living trees in northern-Japan forests. Journal of Forest Research 6:117-120.

Xu, Z., T.D. Leininger, J.G Williams, and F.H Tainter. 2000. Examination of the arborsonic decay detector for detecting bacterial wetwood in red oaks. Southern Journal of Applied Forestry 24:6-10.

Denise Johnstone (corresponding author)

Department of Resource Management and Geography

School of Land and Environment

The University of Melbourne

500 Yarra Boulevard

Richmond, Victoria, 3121, Australia

denisej@unimelb.edu.au

Gregory Moore, Ph.D.

Department of Resource Management and Geography

School of Land and Environment

The University of Melbourne

500 Yarra Boulevard

Richmond, Victoria, 3121, Australia

Michael Tausz

Associate Professor

Department Forest and Ecosystem Science

School of Land and Environment

The University of Melbourne

Creswick, Victoria, Australia

Marc Nicolas, Ph.D.

Department of Agriculture and Food Systems

School of Land and Environment

The University of Melbourne

Parkville, Victoria, 3010, Australia
Résumé. L'évaluation du bois dans un tronc d'arbre est essentielle pour déterminer le degré de risque; quoiqu'il en soit, la mesure exacte de la carie en est encore au stade infantile. Une revue des méthodes courantes utilisées pour les mesures sur le terrain de la carie du bois dans les arbres ornementaux est présentée. Les méthodes sont comparées en terme de dommages causés aux tissus de l'arbre, de facilité d'utilisation et de degré de précision. Les outils de détection de la carie qui sont modérément invasifs, tel la perceuse à forage constant, sont précis pour localiser la carie du bois dans un arbre. Par comparaison, les outils informatisés de tomographie sont moins dommageables pour les tissus de l'arbre, mais leur résultats peuvent être plus difficiles à interpréter.

Zusammenfassung. Die Bewertung des Holzes in einem Stamm ist bedeutsam für die Risikoabschätzung, dennoch ist die akkurate Messung von Fäulnis immer noch in ihren Kinderschuhen. Ein Überblick über die gegenwärtigen Methoden zur Feldmessung von Holzzersetzung bei öffentlichen Bäumen wird hier gegeben. Die Methoden werden verglichen in Bezug auf Schädigungen des Baumes, praktikable Anwendung und ihren Grad an Aussagesicherheit. Baumuntersuchungsgeräte mit moderater Zerstörung, wie der Zuwachsbohrer, sind für die akkurate lokale Bestimmung von Fäulnis in einem Baum geeignet. Im Gegensatz dazu sind computer-tomographische Geräte weniger baumzerstörend aber die Ergebnisse sind interpretationsbedürftig.

Resumen. La evaluación de la madera en el tronco del árbol es esencial para medir el riesgo, sin embargo, la precisión de la medición del decaimiento está aún en su infancia. Se presenta una revisión de los métodos actuales usados para mediciones de campo del decaimiento de la madera en árboles del paisaje. Los métodos son comparados en términos del daño causado a los tejidos del árbol, facilidad de uso, y su nivel de precisión. Los aparatos de medición moderadamente invasivos, tales como taladros, son precisos para localizar el decaimiento de la madera en un árbol. En contraste, aparatos de tomografía computarizados son menos dañinos para los tejidos del árbol, pero los resultados pueden ser difíciles de interpretar. 